\title{
Influence of Female boardroom presence on firm value: An analysis on companies listed on B3
}

\author{
Isaac Gezer Silva de Oliveira', Sâmela Pedrada Cardoso², Ricardo Santos \\ Dias $^{3}$, Pedro Borges Júnior ${ }^{4}$
}

\author{
1 Instituto Federal do Espírito Santo - isaacgezer@gmail.com \\ ${ }^{2}$ Universidade Federal do Espírito Santo - samela.cardoso@ifes.edu.br \\ 3 Instituto Federal do Espírito Santo - ricardodossantosdias@gmail.com \\ 4Universidade Federal do Pará - pedro.borges.junior@outlook.com
}

\section{KEYWORDS}

Diversity,

Gender,

Board of Directors,

Market value.

Received 01.10.2018

Accepted 05.12.2018

ISSN 1980-4431

Double blind review

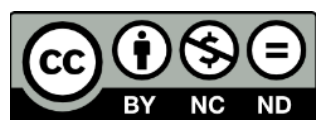

\section{ABSTRACT}

In recent decades women have had substantial advances in access to higher education and the labor market, but these achievements were not reflected in the high ranking of companies. The participation of women in executive positions in the advisory board of large corporations in Brazil and in the world is still incipient. In this sense factors such as patriarchy, male chauvinism, sexism, among other advances not allow the presence of women at the top of large companies, even when this presence is associated with better performance. Thus, work on the assumption that thinking gender diversity of public policies involves ethical issues and inclusion strategies going performance improvement field and value creation, while the completion of ideas and attitudes from the specificities of each gender can contribute to economic and social development of the company. Thus the aim of this study is to investigate the relationship between corporate value and the presence of women in high-ranking. Therefore, we collected data of companies listed on the $\mathrm{B}_{3}$ and identified those with the presence of women on the board and the executive board, checking the differences between them from non-parametric tests. It is still employed multivariate data analysis from the linear regression and probit regression. The results suggest a positive and statistically significant relationship between firm value and the presence of women on the board. The results show evidence that the inclusion of women on the board in addition to ensuring diversity, meet precepts of ethics, equality, social responsibility, contributing to the better performance of firms and generating shareholder value.

\section{PALAVRAS-CHAVE}

Diversidade,

Gênero,

Conselho Administrativo, Valor de mercado.

\section{RESUMO}

Nas últimas décadas, as mulheres tiveram avanços substanciais no acesso ao ensino superior e ao mercado de trabalho, mas essas conquistas não se refletiram no alto ranking das empresas. A participação de mulheres em cargos executivos no conselho consultivo de grandes corporações no Brasil e no mundo ainda é incipiente. Nesse sentido, fatores como o patriarcalismo, o machismo, o sexismo, entre outros avanços, não permitem a presença de mulheres no topo das grandes empresas, mesmo quando essa presença está associada a um melhor desempenho. Assim, trabalhar no pressuposto de que pensar diversidade de gênero nas políticas públicas envolve questões éticas e estratégias de inclusão indo campo de melhoria de desempenho e criação de valor, enquanto a conclusão de ideias e atitudes das especificidades de cada gênero pode contribuir para o desenvolvimento econômico e social da empresa. Assim, o objetivo deste estudo é investigar a relação entre valor corporativo e a presença de mulheres no alto escalão. Por isso, coletamos dados de empresas listadas no B3 e identificamos aqueles com a presença de mulheres no conselho e na diretoria executiva, verificando as diferenças entre eles a partir de testes não paramétricos. É ainda utilizada a análise multivariada de dados a partir da regressão linear e da regressão probit. Os resultados sugerem uma relação positiva e estatisticamente significativa entre o valor da empresa e a presença de mulheres no conselho. Os resultados mostram evidências de que a inclusão das mulheres no conselho, além de garantir a diversidade, atende aos preceitos da ética, da igualdade, da responsabilidade social, contribuindo para o melhor desempenho das empresas e gerando valor ao acionista. 


\section{Introduction}

The diversity of gender is an issue in increased attention, not only in social and journalistic level but also at the academic level. Given the nascent women's participation in top management of large companies, several countries have established in recent years laws of incentives to female presence on company boards, intensifying the debate on the subject.

Factors such as patriarchy, sexism, and others do not allow substantial advances of female presence in senior large companies, even when this presence is associated with better performance.

A study by the School of Law of São Paulo's Getúlio Vargas Foundation (Silveira, Donaggio, Sica \& Ramos, 2014) shows that between the years 1997 and 2012 the presence of women in senior positions in Brazilian companies traded remained stagnant $8 \%$. In the analyzed period, there was an increase $4.2 \%$ to $7.7 \%$ of the participation of women in the Executive Board, though there was a $9.8 \%$ reduction to $7.5 \%$ of the female participation in the Board of Directors. The authors also point out that about half of public companies do not even have a female officer on the Board and in $66 \%$ no woman is part of the Executive Board.

Empirical research indicates disagreement on the relationship between women's participation in top management and financial performance (Terjesen \& Singh, 2008). Nevertheless, there is congruence that executive boards and boards of directors with greater gender diversity reveal good corporate governance practices and commitment to social responsibility and ethics.

Thus, public policy think gender diversity means ethical issues and inclusion strategies going to improve field performance of the companies, while the diversity and specificities of each gender can contribute to economic and social development of the company.

The purpose of this article is to go beyond ethical and moral discussion of gender equality in opportunity to access the top of large corporations, analyzing the companies in which there is a greater presence of women in high places has a higher level of financial performance and value market. In this sense, the objective of this study is to analyze the relationship between performance, market value and the presence of women on the board of companies listed on Brasil, Bolsa, Balcão S.A).

The study, in addition to this introductory section, was organized with the theoretical platform which surveys about gender diversity in organizations, social and environmental responsibility and corporate governance. Consequently, the materials and methods used in research and exposing the delimitations analysis techniques employed are shown. In the subsequent section presents the search results and a brief discussion of the evidence. Finally, the conclusion highlights the contribution of the study and points out suggestions for future studies that explore the methodological limitations of the scope of this research.

\section{Theoretical Framework}

\subsection{Diversity and Gender in Organizations}

In recent years women have had substantial advances in higher education and in the labor market, but these achievements were not reflected in the high ranking of companies. When they observed the foundation of businesses and middle management the presence of women is expressive tending to equalize the female presence, but when analyzed top management (directors and executive officers) female participation reduces dramatically, with a sharper fall occurs when CEOs and Chairmen of the Board women are observed.

Nevertheless, the international literature lists several benefits of gender diversity in top management that can contribute to business performance. In this sense, the presence of women can increase the performance of the company while the participation of women on the board provides other points of views in decision making, providing greater efficiency in the process.

Thus the presence of women in high places should be discussed in the business outlook and moral perspective (Brammer, Millington and Pavelin, 2007), resulting in several benefits, such as increased creativity and innovation, given that attitudes and knowledge systematically vary from genre to gender; a better market understanding; more efficient solutions, while the homogeneity leads to a narrow look while diversity leads to a wider view (Robinson \& Dechant, 1997).

Carter, Simkins and Simpson (2003) found a positive relationship between the presence of

Revista de Negócios, v. 23, n. 3, p. 49-58, July, 2018. 
women and the market value of 638 companies listed in the Fortune 1000. Therefore, Krishnan and Park (2005) analyzed the relationship between diversity in top management and return on investment in the Fortune 1000 companies. The results showed a positive relationship between diversity and financial performance.

Rodríguez-Domínguez, García-Sanchez and Gallego-Álvarez (2012) analyzed 117 companies listed on the Madrid Stock Exchange. The authors concluded that women have a higher performance in sectors dominated by men such as energy, oil, construction and basic materials and technology and telecommunications.

Moreover the study of Campbell and Vera (2010) who analyzed the short- and long-term effect on the capital market when companies announce the presence of a woman in top management stock market reacts positively in the short term for the announcement of the appointments board female, suggesting that investors on average believe that female directors add value. The regression results also confirmed that the female board appointments are positively associated with the company's value in the long term.

Lückerath-Rovers (2013) examined the financial performance of Dutch companies with and without women on their boards. The survey results show that companies with female directors have a better performance than those without women on their executive boards.

Once, studies have not confirmed the positive relationship between women's presence in top management and financial performance. The study by Campbell and Mínguez-Vera (2008) showed that the presence of women on the board, only, does not influence the value of the company. Already Adams and Ferreira (2009) observed a negative average effect between gender diversity and corporate performance.

In view of the results presented, the demand is pointed out to explore this field of research looking at the context in which companies operate and characteristics of these. The relevance as well as the social and economic nature theme arouses attention from society, investors, shareholders and managers, causing reflections and contributions for discussion.

\subsection{Corporate Governance}

Corporate Governance it is a set of legal norms, cultural and institutional arrangements that determine the actions, control and monitoring of public companies. This set of practices determines, therefore, that the public companies can do, as their control is exercised and how they are allocated their risks and returns (Blair, 2005).

Due to the importance of corporate governance has increasingly sought best practices from market incentives due to the increase of competitiveness to institutional and governmental initiatives (Silveira, 2015). In the Brazilian capital market was established in 2001 to Law 10,303 establishing a reform of corporate law in order to establish greater protection to minority shareholders. The BNDES (Development National Bank) has adopted preferential lending requirements for the adoption of good governance practices and beyond the CVM establish recommendations on good corporate governance practices, key players of the capital market have edited governance codes that are guides that link good practices governance recommended by the Brazilian Institute of Corporate Governance.

An important advent in order to improve governance practices in Brazil was the creation of the Novo Mercado and differentiated Corporate Governance Levels by Bovespa in 2001, which were inspired by the experience of the neuer markt German. The process of innovation had this experience is that there was no need to establish new legislation not impacting therefore on companies that already had its publicly traded but opted to continue listed in traditional markets with weaker corporate governance mechanisms (Carvalho, 2002).

The corporate governance levels were created with the intention of highlighting companies committed to best practices in governance. So companies can voluntarily adhere to three different levels created by Bovespa: Level 1 and 2 and Novo Mercado.

Companies listed in level 1 are committed to greater transparency in the information to the market and the free float. Already listed companies at level 2 include all Level 1 requirements plus a range of governance practices and additional rights for minority shareholders. The Novo Mercado, in turn, establishes a pattern of highly differentiated corporate governance and requires companies to meet the precepts of Level 2 and decide only issue common shares to the detriment of the preferred

Revista de Negócios, v. 23, n. 3, p. 49-58, July, 2018. 
shares (without voting rights), and additional governance practices to those required the legal apparatus.

Moreover, Silveira (2015) points out that an effective governance system should combine different internal and external mechanisms in order to ensure choices in the best interest of the shareholders in the long term. The internal mechanisms can be developed by the company, such as board of directors, ownership concentration and remuneration system. As for the external mechanisms are governance practices of agents external to the corporation, such as legal protection to shareholders, the company's regulatory control and executive labor market (Jensen \& Murphy, 1990; Silveira, 2015).

Thus the markets of incentives combined with legal, governmental and institutional measures can contribute to the strengthening of good corporate governance practices and consequently the Brazilian capital markets, providing the highest level of protection for investors thus feel safer to obtain higher returns, thus willing to pay higher values for the shares. Indeed, companies increase the alternative use of the capital market for financing and capitalization of its business. Silveira (2004) classifies these relationships as a virtuous circle proposed for corporate governance in Brazil.

\subsection{Performance and Market Value}

The raised literature suggests that the carrying performance and the market value of firms can be explained by a greater diversity in the command lines. Performance is usually measured in terms of profits, prices and rates of return with appropriate use of accounting and financial ratios through various models applying techniques relevant statistics (Assaf Neto, 2010).

The financial indicators are most often used to measure the construct financial performance of companies was the most reported in empirical studies. Profitability measures are important financial ratios to assess the profits of an enterprise in relation to a particular level of sales, assets or owners investments. Profitability is substantial to attract investors and foreign capital (Carter, Simkins \& Simpson, 2003; Rodríguez-Domínguez, García-Sanchez \& Gallego-Álvarez, 2012; Lückerath-Rovers, 2013).

Once it is crucial for public companies to create corporate value generation to its shareholders, which is its main long-term objective. In this sense, are ample empirical investigations using market indicators as a performance measure to be explained by a set of governance and sustainability practices such as diversity on the board and executive management (Campbell \& Mínguez-Vera, 2008; LückerathRovers, 2013).

2.4 Social Responsibility and Sustainability and Diversity in Organizations

Given the scale and increased concern for the environment and social and sustainable development, managers and investors have given more attention to the actions of sustainability and corporate social responsibility thus includes the environmental variable in the strategies and practices of companies. This perspective led financial markets to seek indexes that enable reflections on the performance of companies in efforts to corporate sustainability (Melo, Almeida \& Santana, 2012).

Therefore following the trend of the main stock exchanges worldwide B3 launched in 2005 the Corporate Sustainability Index, in order to reflect the return of a portfolio which has in its composition stocks of companies that have a commitment to corporate sustainability. Thus the index also has the objective of being a catalyst for good practices in the Brazilian corporate environment (Bovespa, 2014).

For composition of the index, it was considered the 150 most liquid shares in the 12 months preceding the assessment, the fact of having been traded in at least 50 percent of trading sessions in the last 12 months and the service to the Sustainability Index sustainability criteria business. For both are sent performance evaluation of comprehensive questionnaires on four requirements: Economic Efficiency, Environmental Balance, Social Justice and Corporate Governance. The completion of the questionnaire is voluntary and its analysis is done with statistics and multivariate technique.

The ISE is therefore in an index that measures the average return on a theoretical portfolio composed of shares of companies listed on the São Paulo Stock Exchange (B3) and are characterized by strategic alignment to sustainability by adopting practices that contribute

Revista de Negócios, v. 23, n. 3, p. 49-58, July, 2018. 
to sustainable development.

It is noteworthy also that the B3 Corporate Sustainability was developed based on the concept "Triple Bottom Line" that involves the assessment of environmental, social and economic-financial aspects in an integrated manner. It even adopts indicators of corporate governance, as well as nature and characteristics of the product.

\section{Methodology}

\subsection{Strategy Research}

The methodological approach used in the study was quantitative with empirical-analytic approach, in which operationalized as dependent and independent variables in order to determine functions and from data processing to establish relationships between variables are employed (Martins, 2002). Furthermore, the study seeks to explain the practice observed from past data in order to understand more deeply the phenomena occurred and predict unobserved phenomena (Watts \& Zirmmerman, 1986). In short, this research is assumed as quantitative with descriptive purposes and empirical-analytic approach.

\subsection{Definition of Research and Sample}

The limitations of the research comprises in companies listed on the B3. Among the listed companies was selected the top 100 companies on liquidity of share trading. The selection of companies for the sample by the liquidity criterion should be the assumption that low liquidity companies have a lower probability of having adequate prices to its real market value (Silveira, Barros \& Famá 2003). Since there is no accepted standard in the literature to determine a satisfactory degree of liquidity, the number of companies established for the sample made use of concern for the sample size in order to conduct valid inferences and meet the assumptions of econometric modeling.

The years selected for the study were 2012 , 2013, 2014 and 2015 amounting to 300 observations. Data were collected through software Thomson Reuters and ComDinheiro, portal BMF\&Bovespa and reference forms available by CVM. Data analysis was performed using Stata 12 software.

\subsection{Hypothesis}

Founded on the principles of corporate governance, social responsibility and importance of diversity in organizations was formulated the following research hypothesis: The presence of women in board of directors is positively related to performance and creating corporate value, Ceteris paribus.

\subsection{Operationalization of variables}

To test the above hypotheses were selected some proxies based on the theoretical framework and available data. For the dependent or response variable was selected firm value and financial performance.

Regarding the performance adopted the ROA variable (return on Assets) representing the return on total assets, measured by net income divided by average total assets. Concerning the corporate value we used the Tobin's Q which is defined from the following formulation, suggested in studies of Chung and Pruit (1994):

$$
\text { Tobin's Q }=(\mathrm{MVE}+\mathrm{PS}+\mathrm{DEBT}) / \mathrm{TA}
$$

Where: MVE is the product of a firms share price and the number of common stock shares outstanding; PS is the liquidating value of the firm's outstanding preferred stock; DEBT is the value of the firms short-term liabilities net of its short-term assets, plus the book value of the firms long-term debt; and TA is the book value of the total asses of the firm.

In the independent variable the presence of women on the board was captured. They were employed also some proxies as a model of control, such as corporate governance from the company's ranking in the Novo Mercado; sustainability through the company's presence in the BMF\&Bovespa Sustainability Index. The concentration of property, measured as the percentage owned by the three largest shareholders, the frame size of board members and company size, measured by total assets were included in the analysis. Table 1 summarizes the variables used in the study.

Table 1 - Research general variables

\begin{tabular}{c|c|c}
\hline \multicolumn{2}{c|}{ Dependent Variable } & Measurement method \\
\hline Firm Value & TQ & Tobin's q $=(\mathrm{VMA}+\mathrm{D}) / \mathrm{AT}$ \\
\hline Performance & ROA & EBIT/Total Assets \\
\hline
\end{tabular}

Revista de Negócios, v. 23, n. 3, p. 49-58, July, 2018. 


\begin{tabular}{|c|c|c|c|}
\hline \multicolumn{2}{|c|}{ Independent variables } & \multirow{2}{*}{$\begin{array}{c}\text { Measurement } \\
\text { method } \\
\text { Dummy: } 1 \text { if } \\
\text { there is any } \\
\text { woman on the } \\
\text { board, } 0 \\
\text { otherwise. }\end{array}$} & \multirow{2}{*}{$\begin{array}{c}\text { Expected } \\
\text { relation } \\
\text { Positive }\end{array}$} \\
\hline $\begin{array}{l}\text { Female } \\
\text { presence on } \\
\text { the board }\end{array}$ & FEMALE & & \\
\hline Ownership & OWC & $\begin{array}{c}\text { Relative } \\
\text { property of the } \\
\text { three major } \\
\text { owners }\end{array}$ & Control \\
\hline Board size & $\mathrm{SC}$ & $\begin{array}{c}\text { Natural } \\
\text { logarithm of the } \\
\text { number of board } \\
\text { members }\end{array}$ & Control \\
\hline Firm size & SIZE & $\begin{array}{c}\text { Natural } \\
\text { logarithm of } \\
\text { total assets }\end{array}$ & Control \\
\hline Governance & GOV & $\begin{array}{c}\text { Dummy: } 1 \text { if the } \\
\text { company } \\
\text { belongs to Novo } \\
\text { Mercado on B3 } \\
\text { governance } \\
\text { classification, } 0 \\
\text { otherwise }\end{array}$ & Control \\
\hline Sustainability & ISE & $\begin{array}{c}\text { Dummy: } 1 \text { if the } \\
\text { company is part } \\
\text { of the } \\
\text { Susatinability } \\
\text { Index (Indice de } \\
\text { Sustentabilidade } \\
\text { Empresarial) of } \\
\text { B3, } 0 \text { otherwise. }\end{array}$ & Control \\
\hline
\end{tabular}

${ }^{\star}$ Dependent variable of the research model.

3.4 Data Analysis Technique and Econometric Model

Data were analyzed from a linear regression model. Gujarati (2012) points out that the linear regression seeks to measure the statistical dependence of a dependent variable with other explanatory variables and estimated the average value of the dependent variable based on known values of other variables. Hair, Black, Babin, Anderson and Tatham (2006) adds that the multiple regression analysis consists of a multivariate statistical technique used to examine the relationship between a dependent variable (criterion) and other predictors (explanatory) and can be expressed by the following basic formulation, as Fávero, Belfiore, Silva and Chan (2009):

$$
y=\alpha+\beta_{1} X_{1}+\beta_{2} X_{2}+\beta_{k} X_{k}+\varepsilon
$$

Where,
$\mathrm{Y}$ is the dependent variable

$\mathrm{X} 1+\mathrm{X} 2+\mathrm{Xk}$ are independent variables

$\mathrm{B} 1, \beta 2 \ldots \beta \mathrm{k}$ are the regression parameters;

And $\varepsilon$ is the error term, also known as waste

Employees data were submitted to econometric analysis to give birth multiple linear regression (MLR) consisting of a regression model containing more than one regressor. Quantitative variables that represent the values of attributes that can be counted or measured in each element of the sample were used.

The form used to find the coefficients of the regression equation was the method of least squares (OLS Pooled). This method seeks to find the best fit for a set of data from minimizing the sum of squares of differences between estimated and observed values, these differences are called waste (Wooldridge, 2010; Gujarati, 2012).

Thus, the econometric models designed to test the hypothesis research were described as following models:

$$
\begin{gathered}
\text { Performance } \alpha+\beta_{1} \text { Female }_{i t}+\sum_{\mathrm{j}=1}^{\mathrm{k}} \delta_{\mathrm{j}} \text { Control }_{j i}+\varepsilon_{i}(1) \\
\text { FirmValue }=\alpha+\beta_{1} \text { Female }_{i t}+\sum_{\mathrm{j}=1}^{\mathrm{k}} \delta_{\mathrm{j}} \text { Control }_{j i}+\varepsilon_{i}(2)
\end{gathered}
$$

T-test mean differences and probit regression analysis was also proceeded to capture as performance and value variables influence the probability of presence of women in high-ranking of the companies analyzed.

The t-test analyzes the means of two populations are statistically different. Thus we analyzed the mean difference between groups of companies with women on the board and who do not. According to Favero et al (2014) the t-test is obtained from:

$$
T=\frac{(\bar{X}-\bar{Y})-\left(\mu_{1}-\mu_{2}\right)}{\sqrt{\frac{s_{1}^{2}}{n_{1}}+\frac{s_{2}^{2}}{n_{2}}}} \sim t_{\nu}
$$

In the given variable has Student distribution with degrees of freedom, wherein:

$$
\nu=\frac{\left(\frac{s_{1}^{2}}{n_{1}}+\frac{s_{2}^{2}}{n_{2}}\right)^{2}}{\frac{\left(\frac{n_{1}^{2}}{n_{1}}\right)^{2}}{n_{1}-1}+\frac{\left(\frac{n_{2}^{2}}{n_{2}}\right)^{2}}{n_{2}-1}} .
$$

The probit regression analysis (regression probit ordered) is used to explain the behavior of a

Revista de Negócios, v. 23, n. 3, p. 49-58, July, 2018. 
binary dependent variable depending on a cumulative distribution of a normal standard. It is the model that is derived from a variable called latent (Gujarati, 2012). where:

$$
Y^{*}=\beta_{0}+X \beta+\varepsilon
$$

Where $\mathrm{y} *$ is the latent variable, determined by $\beta$, x, vector of explanatory variables, $\varepsilon$, the component error with standard normal distribution.

$$
\operatorname{Prob}\left(Y_{i}=1 \mid X_{i}\right)=F\left(x{ }_{i} \beta\right)=\Phi\left(x{ }_{i} \beta\right)
$$

Where $\Phi($.$) is the cumulative distribution$ function of a normal standard

In this case the probit model was used to estimate the probability of female presence on the board. Soon the variable Y takes the value 1 for companies with women on their boards, and 0 otherwise. The probit regression models structured manner according to equations 3 and 4, the ROA and Q Tobin variables were included in different models given high serial correlation.

$$
\begin{aligned}
& \operatorname{prob}(\text { Female })=1 \mid x)=\phi\left(\beta_{1} \text { Performance }_{i t}+\sum_{\mathrm{j}=1}^{\mathrm{k}} \delta_{\mathrm{j}} \text { Control }_{j i}\right)+\varepsilon_{i} \\
& \operatorname{prob}(\text { Female }=1 \mid x)=\phi\left(\beta_{1} \text { FirmValue }_{i t}+\sum_{\mathrm{j}=1}^{\mathrm{k}} \delta_{\mathrm{j}} \text { Control }_{j i}\right)+\varepsilon_{i}
\end{aligned}
$$

\section{Results and Discussion}

The regression results with the estimated coefficients, robust standard errors $t$ and statistical

\begin{tabular}{|c|c|c|c|}
\hline & & $\begin{array}{l}\text { (1) } \\
\text { TQ }\end{array}$ & $\begin{array}{c}(2) \\
\text { ROA }\end{array}$ \\
\hline \multirow[t]{2}{*}{ INTERCEPT } & $\beta$ & $1.575 * * *$ & $29.27 * * *$ \\
\hline & se & 0.625 & 12.86 \\
\hline \multirow[t]{2}{*}{ FEMALE } & $\beta$ & $0.508 * * *$ & $15.50 * * *$ \\
\hline & se & 0.251 & 5.16 \\
\hline \multirow[t]{2}{*}{ SIZE } & $\beta$ & $-2.66 * * *$ & $-4.88 * *$ \\
\hline & se & 1.03 & 2.12 \\
\hline \multirow[t]{2}{*}{$\mathrm{SC}$} & $\beta$ & $-0.074^{*}$ & $-1.70 *$ \\
\hline & se & 0.047 & .155 \\
\hline \multirow[t]{2}{*}{ OWC } & $\beta$ & $0.014 *$ & .153 \\
\hline & se & 0.007 & .973 \\
\hline \multirow[t]{2}{*}{ GOV } & $\beta$ & $0.511 *$ & 5.19 \\
\hline & se & 0.304 & 5.31 \\
\hline \multirow[t]{2}{*}{ ISE } & $\beta$ & $-0.900 * * *$ & $-13.55^{* *}$ \\
\hline & se & 0.258 & 6.269 \\
\hline
\end{tabular}
coefficient of determination (R2) are shown in Table 2.

Table 2 - Linear Regression Results

\begin{tabular}{lcc}
\hline $\mathrm{R}^{2}$ & 0.3991 & 0.3447 \\
$\mathrm{~F}$ & 6.61 & 5.02 \\
Prob > F & 0.000 & 0.000 \\
Shapiro-Francia & 0,16 & 0,11 \\
Breuch-Pagan & 0,54 & 0,25 \\
Estat VIF Mean & 2,25 & 1,38 \\
\hline Source: Research data. & &
\end{tabular}

The results indicate that performance and corporate value showed a positive and statistically positive relationship with female participation on the board of the companies analyzed, confirming the hypothesis in the research. These results corroborate previous research findings (Carter et al, 2003; Krishnan \& Park, 2005; Campbell \& Vera, 2010; Lückerath-Rovers, 2013 RodríguezDomínguez, García-Sanchez and Gallego-Álvarez, 2012.).

As for model validation tests were performed the Breuch-Pagan test indicating no problems with heteroscedasticity. The ShapiroFrancia test demonstrated that there are no problems with normality in the selected sample, while the statistical VIF (Variance Inflation Factors) demonstrated the absence of multicollinearity.

By making the average difference test, reported in Table 3, among the companies that have the presence of women on the board and those without, the null hypothesis of equal averages for variables (Tobin's Q and ROA) was rejected a 0.01 significance level. Thus, the results indicate that in the period analyzed, companies with female presence on the board had a better financial performance and a better market value than the others analyzed in the sample.

Table 3 - T-test for mean differences

\begin{tabular}{c|c|c|c|cc}
\hline & & $\begin{array}{c}\text { Compani } \\
\text { es with } \\
\text { women } \\
\text { on the } \\
\text { board. }\end{array}$ & $\begin{array}{c}\text { Compani } \\
\text { es } \\
\text { without } \\
\text { women } \\
\text { on the } \\
\text { board }\end{array}$ & $\begin{array}{c}\text { Test's } \\
\text { statisti } \\
\text { cs }\end{array}$ & $\begin{array}{c}\text { P- } \\
\text { value } \\
\text { sirmValue }\end{array}$ \\
\cline { 3 - 6 } $\begin{array}{c}\text { Performan } \\
\text { ce }\end{array}$ & $t$ & 1.436 & 0.886 & -2.249 & $\begin{array}{c}0.00 \\
0\end{array}$ \\
\hline \begin{tabular}{c} 
Source: Research data. \\
\cline { 2 - 5 }
\end{tabular} & 9.42 & 5.21 & -2.78 & $\begin{array}{c}0.00 \\
1\end{array}$ \\
\hline
\end{tabular}

It was therefore proceeded to Probit analysis, used to measure the presence of women on board when the companies making up the sample. The results are shown in Table 4. 
Table 4 - Probit regressions results

\begin{tabular}{|c|c|c|c|}
\hline \multirow{3}{*}{ TQ } & & FEMALE (3) & FEMALE(4) \\
\hline & $\beta$ & $0.4048 * *$ & \\
\hline & se & 0.230 & \\
\hline \multirow{2}{*}{$\mathrm{ROA}$} & $\beta$ & & $0.083 * * *$ \\
\hline & se & & 0.016 \\
\hline \multirow{2}{*}{ OWC } & $\beta$ & $-0.055 * * *$ & $-0.05 * * *$ \\
\hline & se & 0.017 & 0.016 \\
\hline \multirow{2}{*}{ SIZE } & $\beta$ & 3.88 & 4.43 \\
\hline & se & 3.35 & 3.55 \\
\hline \multirow{2}{*}{$\mathrm{SC}$} & $\beta$ & 0.068 & 0.098 \\
\hline & se & 0.098 & 0.101 \\
\hline \multirow{2}{*}{ GOV } & $\beta$ & $1.95 * * *$ & $1.91 * * *$ \\
\hline & se & 0.7331 & 0.755 \\
\hline \multirow{2}{*}{ ISE } & $\beta$ & 0.169 & 0.134 \\
\hline & se & 0.582 & 0.5725 \\
\hline SECTOR & & Yes & Yes \\
\hline Prob > chi 2 & & 0.0000 & 0.0000 \\
\hline Pseudo R2 & & 0.3252 & 0.4269 \\
\hline Hosmer-Lemeshow & & 0.6689 & 0.8576 \\
\hline Correctly Classified & & 0.8395 & 0.8555 \\
\hline
\end{tabular}

Source: Research data.

In the first probit model it is possible to identify positive and statistically significant association between the market value and the company's likely to have women on their board of advisors. It is also observed a positive association of corporate governance and denial of ownership concentration in the probability of presence of women on the boards of the analyzed firms. In the second model the relationships are similar, marking the explanatory variable financial performance also shows a positive association with the dependent variable.

The results are consistent with the literature, demonstrating that better performance associations and creating corporate value with the presence of women at the top of organizations. It also points out that companies with best governance practices are more likely to having women in senior, despite the lower the higher ownership concentration the possibility of female presence on company boards.

Another result can be seen from the insertion of control variables by sector of activity of the companies analyzed. Companies in the paper and pulp industry, energy and transport, showed a negative and significant association with the predicted variable, while the oil sector and consumer staples showed statistically positive association with the presence of women on the board.

\section{Conclusion and Recommendations}

This study aimed to analyze the relationship between market value performance and the presence of women on company boards of directors listed on the B3. To do so was established the hypothesis, based on the theoretical platform that the presence of women on the board is positively related to performance and creating corporate value.

Search results a direct relationship between the proportion of women in senior and the financial and market performance of the analyzed companies, confirming the research hypothesis and suggesting the importance of greater female participation in senior management in order to corroborate the performance and corporate social responsibility, serving performance perspective in business and ethical aspirations in the design of gender diversity.

Thus it follows that it is important to reflect on the development of women's access policies in top management of Brazilian companies, seeking precepts of ethics, equality, social responsibility and prepositions of better performance and corporate value. In this sense the research provides practical results for shareholders, managers, investors, government, regulatory agencies and Society.

How search limitations point to the limited sample size and the fact the sample is restricted to public companies in the face of data availability. Regarding the method we need to consider the effects of endogeneity that can lead to reverse causality. Another limitation can be noted regarding the proxies for governance and sustainability that are based on the presence of indexes which cannot reflect completely such constructs.

It is suggested in future research to expand the sample and consider the use of study in private companies. As the governance variables and sustainability, it would be interesting to approach other metrics to measure them. It would be interesting to consider using dynamic models as a way to mitigate potential effects of reverse causality. Finally suggest to study the developments focusing on management council

Revista de Negócios, v. 23, n. 3, p. 49-58, July, 2018. 
and executive board separately and with the inclusion of variables that capture the social effects of integration of women in those tables.

\section{References}

Adams, R. B. \& Ferreira, D. (2009). Women in the boardroom and their impact on governance and performance. Journal of financial economics, v. 94, 291-309.

Assaf Neto, A. (2010). A Estrutura e análise de balanços: um enfoque econômicofinanceiro. 9. ed. São Paulo: Atlas.

Blair, M. M. (1995). Ownership and Control. Washington: Brookings Instituicion.

Bovespa. (2015). Mercado: Ações - Índices. Retrieved from: http://bovespa.com.br.

Brammer, S., Millington, A. \& Pavelin, S. (2007). Gender and Ethnic Diversity Among UK Corporate Boards, Corporate Governance, v. 15, p. 393-403.

Campbell, K. \& Mínguez-Vera, A. (2008). Gender Diversity in the Boardroom and Firm Financial Performance. Journal of Business Ethics, 83 (3), 435-451.

Campbell, K. \& Vera A. M. (2010). Female board appointments and firm valuation: short and long-term effects. Journal Management Governance. 14:37-59. doi: 10.1007/s10997-009-9092-y.

Carter, D. A., Simkins, B. J. \& Simpson, W. G. (2003). Corporate governance, board diversity, and firm value. Financial Review, 38: 33-53.

Carvalho, A. G. (2002). Governança Corporativa no Brasil em perspectiva. Revista de Administração da USP, v. 37, n. 3.

Chung, K. H., \& Pruitt, S. W. (1994). A simple approximation of Tobin's q. Financial Management, 70-74.

Favero, L. P., Belfiore, P., Silva, F. L. \& Chan, B. L. (2009). Análise de Dados: Modelagem Multivariada para Tomada de Decisões, Elsevier - Campus, Rio de Janeiro.

Hair, JR, Black, W. C., Babin, B. J., Anderson, R. E \& Tatham, R. L. (2006). Multivariate Data Analysis. 6 ${ }^{\mathrm{a}}$ edição. Upper Saddle
River, NJ: Pearson Prentice Hall.

Jensen, M. C. \& Murphy, K. J. (1990) Performance Pay and Top-Management Incentives, Journal of Political Economy, v. 98, n. 2, pp. 225-264.

Krishnan, H. A. \& Park, D. (2005) A few good women - on top management teams, Journal of Business Research, v. 58, p. 1712-1720.

Luckerath-Rovers, M. (2013). Women on boards and firm performance. Journal Managemant Governance. 17:491-509. doi: 10.1007/s10997-011-9186-1.

Martins, G. A. (2002). Manual de elaboração de monografias e dissertações. 3. ed. São Paulo; Atlas.

Melo, E. C., Almeida F. M. \& Santana G. A. (2012). Índice de sustentabilidade empresarial (ise) e desempenho financeiro das empresas do setor de papel e celulose. Revista Contabilidade e Controladoria. v. 4, n. 3.

Robinson, G. E. \& Dechant, K. (1997). Building a business case for diversity, Academy of Management Executive, 11 (3), 21-31.

Rodríguez-Domínguez, L., García-Sánchez, I. \& Gallego-Álvarez, I. (2012). Explanatory factors of the relationship between gender diversity and corporate performance, European Journal of Law and Economics, 33(3), 603-620.

Silveira, A. D. M., Barros, L. A. B. D. C., \& Famá, R. (2003). Estrutura de governança e valor das companhias abertas brasileiras. Revista de Administração de Empresas, 43(3), 5064.

Silveira, A. M. (2004) Governança corporativa e estrutura de propriedade: determinantes e relação com o desempenho das empresas no Brasil. 250 p. (Doctoral Thesis) Faculdade de Economia, Administração e Contabilidade, Universidade de São Paulo, São Paulo.

Silveira, A. D. M. (2015). Governança corporativa no Brasil e no mundo: teoria e prática. Elsevier Brasil.

Silveira, A. M. \& Donaggio, A. R. F., Sica, L. P. P. Revista de Negócios, v. 23, n. 3, p. 49-58, July, 2018. 
P. \& Ramos, L. O. (2014). Women's Participation in Senior Management Positions: Gender Social Relations, Law and Corporate Governance. Retrieved from:

http://dx.doi.org/10.2139/ssrn.2508929

Terjesen, S. \& Singh, V. (2008) Female Presence on Corporate Boards: A Multi-Country Study of Environmental Context. Journal of Business Ethics, vol. 83(1), pages 55-63.

Watts, R. L. \& Zimmerman, J. L. (1986). Positive accounting theory. New Jersey: PrenticeHall.

Wooldridge, J. M. (2010). Econometric analysis of cross section and panel data. MIT Press, Cambridge.

Fávero, L. P., Belfiore, P., Takamatsu, R. T., \& Suzart, J. (2014). Métodos Quantitativos com Stata. Elsevier Brasil.

Gujarati, D. N. (2012). Basic econometrics. Tata McGraw-Hill Education. 